\title{
Price Stabilization During a Period of Cold War
}

\author{
Robert V. Faragher* and Fritz F. Heimann**
}

$\mathrm{D}$

IRECT price controls have been in use as an anti-inflationary measure for slightly over two years. Now, with the change in administration, a re-examination of the entire problem of inflation and of the direct and indirect controls which have been employed as countermeasures is in order. Several fundamentals inust be recognized in any objective approach to this subject:

First, a stable economy is a paramount object of national policy;

Second, we are in a limited emergency of unlimited duration;

Third, for the duration of the emergency we face the prospect of serious threats to economic stability;

Fourth, it is a responsibility of the national government to deal with these threats.

Indirect controls, such as high taxes, credit restraints and other devices of fiscal and monetary policy, must be the first line of defense against inflation. Agreement on this is alnost universal, ${ }^{1}$ even though there is diversity of opinion on how such controls should be administered. While recognizing the inportance of indirect controls, we are concerned here solely with the price control phase of stabilization in a cold-war economy.

An appraisal of the price control prograni suggests strongly that it was unsuited to the conditions of a protracted cold-war period. However, for the duration of this period there will be a number of very serious imflationary problems with which indirect controls cannot cope effectively. To determine the kind of control structure needed to deal with the inflationary dangers of the cold-war period, we must look at the experience of the past, the problems of the present and the threats of the future.

*Associate Chief Counsel, Office of Price Stabilization. Lecturer in Law at the Catholic University of America. Member of the New York, Mllinois and District of Columbia Bars.

**Assistant to the Associate Chief Counsel and Secretary of the Legal Policy Committee, Office of Price Stabilization. Member of the District of Columbia Bar.

The opinions expressed are those of the authors and do not necessarily represent those of the Office of Price Stabilization. The writers wish, however, to acknowledge their deep indebtedness to Professor Gardner Ackley, Department of Economics, University of Michigan, who was formerly Director of the Office of Economic Policy, OPS, and to Franz Wolf, who is presently Deputy Director of the Office of Economic Policy, OPS. Any similarity of our views with theirs is not entirely comcidental. At the same time we do not intend to attribute to them any particular views herein, nor the nuanner of expression or emphasis.

1 See Director, Defense, Controls, and Inflation (1952). This is the transcript of the University of Chicago Law School Conference on the Economics of Mobilization. The participants included many leading economists, lawyers, government officials and industrialists representing a broad spectrum of economic thought.

2 See Galbratte, A Theory of Price Control (1952), particularly cc. 7 and 8, and G. Griffith Johnson, Reflections on a Year of Price Controls, 42 AM. Econ. Rev. 289 (1952). 
The underlying economic conditions of a cold-war period differ fundamentally from those of a total-war period. ${ }^{2}$ In an economy geared to the efforts of an all-out war, inflation is like an acute disease. The danger is general and immediate. During a period of cold-war, inflation resembles a chronic and at times a latent condition. The areas of infection are for the niost part localized. However, there is an ever-present danger of general contagion. Applying the treatment for an acute disease to a chronic or latent condition is apt to cause serious complications. Ignoring the chromic or latent condition would be even more dangerous.

I

The price control program which began in January of 1951 was built largely on the experience gamed in the fight against inflation during World War II. Understandably, it was assumed that the problems confronting OPS would be much the same as those which confronted OPA. ${ }^{3}$ The methods used, therefore, were substantially the same. In fact, many OPS regulations were simply World War II models taken out of mothballs; many OPS officials were OPA administrators, balder and grayer. ${ }^{4}$

As a starting point the OPA experience was helpful. The general freeze of January $1951^{5}$ broke the back of the inflationary movement which started with the invasion of Korea in June of 1950 and gathered momentum when the Chinese intervened in November. ${ }^{6}$ Following the general freeze, efforts were concentrated on "tailored" regulations for particular industries and on adjustment measures to iron out inequities. The pattern of counprehensive direct controls which was developed closely resembled that under OPA.

Over a period of time, however, it became apparent that the underlying economic conditions of the present emergency were not like those of the last war. ${ }^{7}$ The principal differences are these:

(1) During the last war the pressure of inflation was general and unremitting. Virtually everything on the market was pushing against ceilings. ${ }^{8}$ This was as true of mattresses as it was of lamb chops, of tires, coal, machinery, overcoats and just about everything else. When OPS was

3 The initial phenomena seemed quite similar. Strong inflationary pressures were prevalent in virtually all segments of the economy. In comparison with the situation after the outbreak of World War II, the inflationary movements following Korea actually seemed worse. Pressures built up far more rapidly.

4 For example, Harold Leventhal, formerly Chief Counsel; Edward F. Phelps, Director of Price Operations; Gardner Ackley, formerly Director of the Office of Economic Policy; FIarry Stein, Deputy Director of Enforcement; Max Feinberg, Director of the Services Division; Stewart Stranahan and Robert Benes, Division Counsel and Assistant Division Director of the Industrial Materials Division. Ethel Gilbert, Director of Industry Advisory Committees, has withstood the ravages of time and price control unchanged.

5 General Ceiling Price Regulation, 16 FED. REc. 738 (1951).

- Disalte, Price Stabitization to Date, Report to the Senate and House Conmmttees on Bankino and Currency (May 1951); Egan, End of Panic Buying Credited to Freeze, New York Times, May 7, 1951, p. 3.

TSupra note 2.

8 See Mansfield, A Short History of OPA, Historical Reports on War Adnanistration 50-81 (OPA Gen. Pub. No. 15, 1947). 
launched, the inflationary pressures seemed to be of the same pervasive character. In the period following the general freeze, however, the pressure gradually began to ease in many areas. The market prices of many articles fell appreciably below their ceilings. In most of these "soft-market" areas, OPS took steps to suspend controls. ${ }^{9}$ In a good many other areas where sales were being made at or near ceilings, there seemed to be little pressure which could push prices significantly above the ceiling level. It is likely that market forces, not ceilings, determined selling prices.

(2) During the last war the military effort was not merely more massive, but of such overriding urgency that the civilian economy had to be radically curtailed..$^{10}$ During the cold war, on the other hand, the continuation of an uncurtailed and even an expanding civilian economy has been a basic objective of national policy. ${ }^{11}$ Moreover, it is fair to say that this objective is being realized. For example, the tremendous growth which has taken place in the television industry since Korea would have been completely unthinkable during the last war.

(3) The price control program during the last war had a foreseeable end. Controls were an emergency measure which would be lifted when the emergency passed. Although no one knew when the war would end, no one doubted that it would come to a final conclusion. The present cold war is different. It is not an all-out war to the finish. Rather it has as its objective the prevention of such a war. For that reason, no "end" can be foreseen.

The history of the Capehart Amendment, ${ }^{12}$ which OPS fought so bitterly, is a good illustration of the fundamental difference between World War II and cold-war conditions. The amendment allowed manufacturers to adjust their ceiling prices for cost increases up to July 26, 1951. This pushed forward by four to seven months the period of automatic cost escalation, thereby knocking out the OPS requirement that manufactures $a b$ sorb cost increases incurred after earlier cut-off dates. In addition, numerous coinplexities introduced by the amendment made it appear almost impossible to administer with any degree of precision. The irreparable damage to the whole stabilization program, which it was feared would result, ${ }^{13}$ never really materialized despite significant price increases in some areas

\footnotetext{
9 Price Operations Memorandum No. 47, Suspenston Standards for Pramary Raw Materiats (Aug. 20, 1952); Price Operations Memorandum No. 48, Additronat Suspension Standards for Manufactured Goods (Aug. 21, 1952). For the full list of all decontrol and

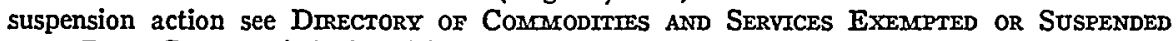
FROXr Price Controc (3d ed. 1952).

10 Production for the current mobilization program amounts to approximately $14 \%$ of total output. At the height of World War II military needs accounted for $45 \%$ of the nation's product.

11 Director of Defense Mobmization, Third Quarterly Report to the President 3 (1951).

1266 STAT. 298 (§ 402(d) (4), 50 U.S.C. APP. § 2102 (d) (4) (Supp. 1952).

13 See President Truman's special message to Congress recommending repeal of the Capehart Amendinent. SEN. Doc. No. 61, 82d Cong., 1st Sess. (1951).

13 a As of January 15, 1953 only 2,591 companies had filed for Capehart relief-less than $1 \%$ of the total of approximately 300,000 manufacturing firms. See Bureau OF CENSUS, DEP'T of Comarerce, Statisticat Abstract 441 (1952).
} 
of the economy, as for example, in automobiles. This fear sprang from the experience in World War II of umiversal, unremitting pressure on ceilings and a generally rising level of costs.

What in fact happened differed sharply from expectations based on the World War II experience. In a number of industries virtually no manufacturers applied for ceiling price adjustments. ${ }^{13 a}$ In some industries the amendment actually gave lower ceiling prices than those previously established.

For two principal reasons the Capehart Amendment was not the disaster which was anticipated. First, a considerable number of manufacturing costs had actually declined from their post-Korean peaks by July 26,1951 . $^{14}$ Second, by the end of 1951 there were many industries in which market conditions had eased to such an extent that manufacturers did not take the trouble to compute the higher ceiling prices to which they were entitled. ${ }^{10}$

The Capehart Amendment is, of course, only one of many examples which point up the differences in economic conditions between World War II and the present cold war. These differences are important, in fact they are of such fundamental importance as to make it highly doubtful whether a regulatory structure based on World War II experience is at all suited to the economic conditions of a protracted cold-war period.

A general system of direct controls is economic medicine of the most drastic kind. For that reason, it should be used only where the need is clear and convincing. Under existing economic conditions, without powerful, across-the-board pressure on prices, that need does not exist.

That the present emergency does not have a foreseeable end is a particularly strong argument against the continuation of a general system of controls. ${ }^{16}$ As with all drastic medicine, prolonged use may be more harmful than beneficial. To be effective, price controls must be simple. However, the longer they remain in use, the more complicated they become. Of necessity, adjustments and refinements must be made. These are needed in order to straighten out inequities, to permit seasonal fluctuations and to make adjustments for changes in economic conditions. ${ }^{1 \tau}$

In a cold-war economy it is much more difficult to keep the operation of controls as simple and inflexible as during a period of total war. ${ }^{18}$ For example, with a civilian economy operating in high gear there is considerable turnover in the products offered for sale. Television is an illustration. The twelve- and fourteen-inch models which were sold when price controls

\footnotetext{
14 For example, natural rubber, wool and cotton linters.

15 These soft markets were in part a "hangover" from the post-Korean boom. Business and consumers had stocked up very heavily in anticipation of possible shortages. The reduced demand in the latter half of 1951 and through the first half of 1952 was probably caused by the fact that excessive inventories had to be worked off. This inventory recession is discussed in Business Roundup, Fortune Mag. 29-30 (June 1952).

16 Field, Economic Stabilization under the Defense Production Act of 1950, 64 HaRv. L. Rev. 1, 2-3 (1950); and Galbratte, op. cit. supra note 2, at 69.

17 For an analysis of the exceedingly complicated state which the ceiling price structure in the consumer durable goods area reached see Heimann, The Regulatory Structure for Consumer Durable Goods-Rococo Run Rampant, 38 Iowa L. Rev. (Winter 1952) (to be published).
} 
went into effect were later completely replaced by nineteen- and twentyone-inch sets. Establishing ceiling prices for new products, as well as for new sellers, is never simple nor satisfactory. Like every other complicating factor this impairs the effectiveness of the whole system. ${ }^{19}$ Paradoxically, the problem is likely to be most difficult in industries where controls are least necessary. It is in these areas that manufacturers attempt to perk up lagging sales by diversifying and expanding their lines with new articles.

There is an important psychological reason against the continuation of comprehensive controls when there is no generally recoginzed need for them. As an instrument which directly affects the daily actions of many millions of individuals, price controls are vitally dependent on community acceptance. Their success depends almost entirely on voluntary compliance. ${ }^{20}$ When the need for their use is not clear and convincing, and when, in addition, they do not work very well, their continuation may breed disrespect and discredit them as an important anti-inflationary weapon for the future.

What has been said so far indicates the dangers and disadvantages of continuing a system of general controls. What are the risks in abandoning this system? To answer that question, we must see what it has accomplished.

II

A general controls system does three things. First, it holds prices in check in those areas where inflationary pressures are present. These include principally the industries allied to defense production. Ninety-four per cent of defense purchases come froin industries where prices were pressing against ceilings. ${ }^{21}$ There can be no doubt that prices in these areas would have risen significantly without controls. For example, during the recent steel dispute the industry contended that the wage increase to its workers required a $\$ 12$ per ton price increase, ${ }^{22}$ more than twice what was ultimately granted. ${ }^{23}$ Even though the industry might not have taken the full $\$ 12$ increase to which it claimed to be entitled, it is safe to say that, in the absence of controls, the increase would have been substantially more than OPS allowed. The effects of such an increase would have been costly to the defense program and would have forced price increases in many steel-using industries. Ample demonstration of what the damaging effects would have been is provided by the allowed increase which necessitated the

\footnotetext{
18 Galbraith, op. cit. supra note 2, at 59-60.

19 See Heimann, supra note 17.

20 See Mansfield, supra note 8, c. VIII, Enforcement.

21 Report of Joseph H. Freehill, Director of Price Stabilization, to Michael V. Di Salle, Administrator of the Economic Stabilization Agency, PRICE INCREASES TO BE ExPECTED IN Case of Removal of Stabinzation Controls (January 19, 1953).

20 Statement of Clarence Randall, President of the Inland Steel Corporation, on behalf of the steel industry, Wall Street Journal, March 22, 1952, p. 1.

23 At the direction of the Acting Director of Defense Mobilization, Dr. John Steelman, OPS provided an increase averaging about $\$ 5.20$ per ton, General Ceiling Price Regulation, Rev. 1, Supp. Reg. 100, 17 FED. REg. 7585 (August 19, 1952).
} 
issuance of a regulation permitting the steel-using industries a "passthrough" of the increased steel cost. ${ }^{24}$

The second function performed by a general price control structure is to prevent another contagious general inflation. The fuel that feeds the fires of inflation is frequently psychologic, rather than economic in origin. ${ }^{25}$ Fear of the future is the principal ingredient, as shown by the events following the invasion of Korea. The outbreak of war, at least initially, did not materially affect demand for current consumption; available supply was entirely adequate for that demand. Inflation was induced mainly by a huge anticipatory demand initiated by the fear of rising prices and of shortages, which caused businesses to expand their inventories and consumers to invest their savings in such things as new automobiles, refrigerators and washing machines. When the general freeze restored confidence in the stability of prices, the panic buying stopped as suddenly as it had begun..$^{20}$ The very existence of controls, therefore, exerts a powerful influence on consumer and business psychology.

As long as the cold-war period continues, and its end is not foreseeable, the danger of outbreaks comparable to Korea will always be present. There can be no doubt that the existence of general controls would avoid inflation by panic.

The third function served by a general control structure is to provide a line of defense against general inflation. The outbreak of a general war, or any other event which would require a substantial increase in military production with a corresponding curtailment in the civilian economy, would unquestionably produce the same violent inflationary pressures which we fáced during the last war. There would be a large excess of demand over available supply, caused by real shortages and not merely by panic buying. ${ }^{27}$

Whether the line of defense provided by the recent controls structure could withstand the full inflationary force of total war is questionable. ${ }^{28}$ The underlying law would undoubtedly have to be strengthened. ${ }^{20}$ Considerable buttressing and bulwarking of the regulatory framework would certainly be essential. It cannot be denied, however, that if total war should break out, the existence of even an imperfect system of controls would be better than none at all.

${ }^{24}$ General Overriding Regulation 35, 17 FED. REG, 8179 (September 10, 1952).

25 See the statement by H. Struve Hensel, former Under Secretary of the Navy, in Direcron, op. cit. supra note 1, at 20-21. The following is particulariy instructive:

It is also hard for me to believe that the Korean situation and even our mobilization plans have had much mechanical effect on today's inflation. Prices have risen substantially, in my opinion, largely because of the impact of Korea and the inobilization of public psychology. If that is correct, should we not seriously consider countermeasures which are purely psychological, and is that not the real justification of the price-control regulations of today?

28 See note 6 , supra.

27 The place of price controls in the operation of a "disequilibrium system" is discussed in cc. 4,5 and 6 of GaxbraItr, op. cit. supra note 2.

28 See Heimann, supra note 17.

29 For example, the provisions of the Capehart Amendment requiring OPS to permit manufacturers to calculate individual ceiling prices would almost certainly have to be eliminated. 
The three functions performed by direct controls-(1) suppression of inflation in areas affected by defense production; (2) protection against inflation by panic; and (3) establishment of a defense line against real inflation in case of all-out war-cannot be performed effectively by imdirect controls. ${ }^{30}$ By definition, indirect controls cannot be selective. For that reason they cannot cope with inflationary pressures localized in the defenseaffected industries. It is impossible, for example, to control the price of steel except by the use of direct controls. As for inflation by panic, the operation of indirect controls is too slow, by the very fact of being indirect, to counter, promptly and head-on, sudden radical increases in consumer demand or in business inventory policy. Finally, in case of all-out war, the inflationary danger would be so great that all anti-inflationary measures, direct as well as indirect, would have to be used to the limit.

We must accept the fact that these three inflationary problems are with us for the duration of the cold war. We may expect the high volume of defense production to continue to stimulate inflationary pressures in those areas of the economy affected by the impact of military production. ${ }^{31} \mathrm{Al}$ though there has been, and will undoubtedly continue to be, large-scale expansion of productive facilities in the defense industries, the size of defense demands is such that any major change in procurement policy will have a decidedly inflationary impact. As for inflation by panic, this will remain a threat as long as the cold war continues, for outbreaks similar to Korea can take place at any time. Total war, too, is a prospect which we dare not disregard.

In short, then, the system of comprehensive controls patterned on the experience of an economy of total war, is not adapted to a cold-war economy. At the same time, it seems clear that grave dangers, both present and future, will confront us as we abandon that system. The issue, then, comes down to this: Can we develop an effective substitute for general controls, a substitute which will provide the needed protection against inflationary threats and yet be tailored to the economic realities of the cold-war period?

III

Most of the trouble with OPS' comprehensive controls program can be traced to our lack of economic preparedness in the summer and fall of $1950 .^{32}$ We were not ready to act when inflationary pressures developed. ${ }^{33}$ It was four weeks after the invasion of Korea before the gravity of the eco-

30 DiSalle, Final Report as Administrator of the Economic Stabilization Agency (January 31,1953 ).

31 Drrector of Defense Mobilization, Eighth Quarterly Report to the Presment 38-39 (January 1, 1953).

32 A sharply critical account of the development of the stabilization program is given by David Ginsburg, first General Counsel of OPA, in Price Stabilization, 1950-52: Retrospect and Prospect, 100 U. of PA. L. Rev. 514 (1952).

33 The efforts of the National Security Resources Board to obtain enactment of an Emergency Powers Act, which included price control provisions, came to naught. 
nomic situation became the subject of Congressional hearings. ${ }^{34}$ From the time the legislative process was set in motion, until the Defense Production Act became law, an additional seven weeks elapsed. ${ }^{35}$ Three more months passed before the administrative machinery was organized to make use of the powers granted by Congress. ${ }^{36}$ Even then only a skeleton crew was on duty. However, the economic situation had already deteriorated to a point where action could no longer be delayed. During the whole first half of 1951 the crew was still being brought aboard after the ship was under way. Much worse than the lack of an adequate staff was the absence of anything remotely resembling an adequate plan of action. Both over-all strategy and specific techniques had to be developed after the crisis was at hand. It was not deliberate choice, but desperate necessity that caused OPS to proceed on the assumption that the problems confronting it were of the same general character as those which confronted OPA during the last war.

Lack of adequate preparations robbed OPS of any real freedom of action. By the time it was able to act, the econounic situation was so out of hand that comprehensive general controls had to be imposed. ${ }^{37}$ An earlier start plus advance planning might have provided an opportunity to try less drastic methods. ${ }^{38}$ For example, if selective controls had been imposed promptly on a relatively small number of highly sensitive commodities it might never have been necessary to impose general controls. ${ }^{30}$

The delay resulting from unpreparedness did not merely make the use of general controls necessary; it impaired their effectiveness from the outset. By the time the general freeze was imposed on January 26, 1951, seven months after the invasion of Korea, prices had surged so far forward and price relationships were so badly distorted that a full-scale readjustment of the price structure was necessary. ${ }^{40}$ The principle adopted in the manu-

34 Both the Senate Banking and Currency Committee and the House Banking and Currency Committee began hearings on July 24,1950 .

35 President Truman signed the Defense Production Act on September 8, 1950.

30 While the Economic Stabilization Agency was set up on September 12 (Exrc. OrDer No. 10161, 15 FED. REg. 6105), it was not until January 24, 1951 tbat OPS was launched (ESA GEN. ORDER No. 2, 16 FED. REG. 738). Since price controls are a very complicated enterprise, lack of preparation is a very powerful deterrent to their use. Authority to act, by itself, is not enougl. One reason why the situation was permitted to deteriorate after legal authority to act had been provided was that no detailed blueprint for action was available.

37 When the general freeze was imposed on January 26, 1951 basic commodity prices had risen almost $50 \%$ since Korea, farm prices $16 \%$, wholesale food prices $12 \%$, industrial prices about $14 \%$, wholesale textile prices over $30 \%$, and chemicals $25 \%$. These figures are cited in the Statement of Considerations accompanying the GCPR, 16 FED. REG. 808 (1951).

38 Before the general freeze an attempt was made to stop the inflationary pressures by voluntary measures. This failed completely. The voluntary pricing standards were issued by Alan Valentine, then Economic Stabilizer, on December 19, 1950 (15 FED. REg. 9255). Several voluntary agreements were made with specific industries and two mandatory regulations were issued before the general freeze, CPR 1, new passenger automobiles, and CPR 2, hides.

39 The advantages to be obtained from the prompt use of selective controls are discussed in Field, supra note 16, at 5.

40 The figures cited in note 37 show how uneven the increases were as between different major segments of the economy. Similar distortions existed hetween different sellers in the same industry and between different levels of distribution. In some cases price increases far exceeded the cost increases actually incurred, in other cases no adequate adjustments for cost incrcases lad been taken. The administration was almost under a moral obligation to inake a readjustment, for a continuation of the freeze would punish those who had complied with the voluntary provisions standards, note 38 supra, and reward those who had ignored them. 
facturing area provided for a return to pre-Korea prices, adjusted to reflect certain changes in costs. ${ }^{41}$ This necessarily made controls far more complicated and therefore less effective. It became much more difficult for the seller to determine his correct ceiling; OPS frequently did not know; and customers hardly ever knew.

The lesson for the future is clear: To act effectively, we must be able to act quickly; therefore, we must be prepared. Economic preparedness means stand-by controls, controls which can be used as soon as their need arises. ${ }^{41 a}$ The development of a stand-by structure for a prolonged cold-war period presents many hard problems. Recognizing the inagnitude of the task, we wish here only to suggest an approach and to indicate some things that need to be done.

Basic to meaningful stand-by controls is an organization equipped to do the job of developing and administering them. As a prerequisite there must be means for determining whether, when, and what controls are needed. This is principally a planming and analysis function. In addition, there is the active regulatory function. Its importance will vary with changes in economic conditions. Under existing economic conditions, the organization should not operate solely on a stand-by basis. It should deal positively with the limited inflationary pressures produced by the present mobilization effort. Uncontrolled, these pressures will affect many other parts of the economy. ${ }^{42}$ In addition and of greater inportance, the organization should be prepared to cope with the far graver problems which the future might bring: Inflaction by panic caused by another Korea; and real inflation produced by the outbreak of total war.

Separate levels of operation should be envisaged. These might be grouped as follows: (1) stand-by; (2) selective controls over materials affected by defense production; (3) selective controls over the civilian econoiny; (4) general controls. The size, character and structure of the orgamization would of course vary, depending on which of the four levels was being used. For example, in the stand-by level of operation there would only be a skeleton group.

The stand-by level would involve a constant searching appraisal of economic conditions. Inflationary forces must be discovered before they generate unstabilizing price movements. Current studies must be maintained in all sensitive and major areas. Plans must be ready for all the more important contingencies. For example, a blueprint for general controls, to be used in the event of total war, should be prepared and kept up-to-date.

41 Ceming Price Regutation 22, the Generad Manufacturer's Regulatron, 16 Fed. REG. 10535 (Oct. 16, 1951).

41aColumbia University's American Assembly released a summary report of the findings of the December 5-7, 1952 Assembly meeting on the subject of inflation. The following conclusions were reached. 'Forces making for inflation are still present. It was agreed that inflation may break out anew with any sudden or serious increase in international tensions ..... On the question of direct controls it was agreed that price and wage ceilings should be removed but that stand-by authority to impose controls should be provided." AMAERICAN Assearbir REPORT: A REAPPRAISAL OF INFLATION 5, 6. 
This would mean not merely regulations, but also planning for personnel and other organizational matters.

The stand-by level should not be viewed as a detached "ivory tower" undertaking. Indeed, there must be constant, close contact with the business community and with government agencies whose programs have significant economic implications, such as the Federal Reserve Board, the military procurement agencies and the Department of Agriculture. Consultation should be both formal and informal. Through the use of industry advisory committees, and other more informal contacts, the agency would obtain vital information. In addition, the industry consultants, having become familiar with problems of price control, would provide an excellent source of manpower for a full-scale controls program in case of total war.

The second level of activity involves selective controls over materials and services affected by the defense program. This is probably the only area of the economy in which direct controls are at present required..$^{43} \mathrm{We}$ have noted before that there are real inflationary pressures in the defense affected imdustries.4 Decontrol in this area may be seriously questioned. Inevitably, the cost of rearmament will be greatly increased. ${ }^{45}$ At the same time, the resulting price increases will not serve any useful function. ${ }^{40} \mathrm{De}$ inand for inaterials will not decline appreciably. Civilian use might decrease slightly; military procurement, however, will hardly be affected. Nor will price increases be apt to increase the supply of defense materials. This goal is achieved far more economically through devices such as subsidies or favorable tax treatment.

The administration of selective controls would necessarily be different from the way comprehensive controls were administered. The OPS standards, with their einphasis on cost absorption, would have to be modified, since far too many costs, probably including wage costs, would remain uncontrolled. (It is doubtful whether wage controls can be administered

42 The importance in the economy of the defense industries is very great. As we have noted in Part II, the increase in steel mill prices had to be passed vertically through the whole economy. The catalytic effects of price increases in starting an inflationary spiral are described in GaIbratth, op. cit. supra note 2, c. 7 .

$43 \mathrm{As}$ controls are lifted in the areas of the economy not affected by defense production, some scattered price increases will unquestionably occur. IIowever, that would be the case regardless when controls were removed. It could only be prevented by keeping them on indefinitely.

44 "The pressures on the Office of Price Stabilization indicate that, were price ceilings to end, prices would increase in the basic metals, in many metal-using products, and in building materials, fuels and other industrial commodities." DIRECTOR OF DEFENSE MOBILIZATION, ErghtH QUARTERLY RePORT TO THE PREsIDENT 38 (January 1, 1953).

45 "With dehiveries of military hard goods and construction running at an annual rate of over $\$ 30$ billion, were an increase of no more than 4 percent in these prices to occur, over $\$ 1$ billion would be added to the annual cost of the program. If there were no controls in this area, the increase in prices would probably be much more than 4 percent. Either high taxes, budget deficits, or a reduced volume of defense equipment would ultimately result." Ibid.

46 The defense industries are characterized by conditions of imperfect competition. It is in areas of imperfect competition that price controls operate most effectively, and have the least undesirable economic consequences. Galbraith's discussion of "Price Control and Market Imperfections" is most illuminating, GaLbRaITH, op. cit. supra note 2, cc. 2 and 3. 
on a selective basis. As for comprehensive wage controls, in all likelihood they can be used only when general price controls are in effect.) Selective controls would have to be fairly flexible. Ceiling price adjustments would have to be made in order to reflect significant cost changes. Such adjustments should be made both for cost increases and for cost decreases. They might be made either at fixed intervals or whenever costs changed by a predetermined amount. ${ }^{47}$

The administration of such a program should not raise insuperable difficulties either for government or for business. The basic techniques which were developed to "pass through" the cost increase following the steel strike might serve as a model. ${ }^{48}$ Many of the fundamental problems involved in the operation of a flexible controls system were encountered in making the steel adjustment.

We have suggested that at the present time there is no need for general controls and probably not even for selective controls over the civilian economy. Nonetheless, the mere existence of legislative authority providing for the imposition of such controls might be enough to prevent inflation by panic. It might give sufficient assurance of price stability so that the excessive inventory accumulation and the panic buying of consumer goods which marked the last half of 1950, would not follow the next flare-up in the cold war.

Furthermore, the ability to act quickly on a selective basis when acute problems arise might well prevent the contagious spread of inflation which would make the use of comprehensive controls necessary. Let us assume, for example, that the communists would gain the upper hand in IndoChina. This would seriously upset our position in Southeastern Aria. The effects on rubber, tin and a number of other important commodities would be immediate. Prompt action to prevent sharp price increases would obviously be of the greatest importance.

We have indicated four separate levels of operation which we believe should be available for use during a protracted cold-war period, but have not touched upon the division of functions between Congress and the Executive under such an operational structure. The issues mvolved are important, difficult and delicate.

The role of Congress in the controls program raises serious difficulties and has been a frequent source of trouble during the recent program. ${ }^{49}$ The difficulties arise because the problem of inflation is both complex and everchanging, which makes it impossible to write a law which spells out in

4r A program of flexible controls was worked out in some detail by the Committee for Economic Development. They advocated a periodic pass through system. See "Price and Wage Controls," Statement on National Policy by the Research and Policy Committee of the Committee for Economic Development (December 1951).

48 General Overriding Regulation 35, supra note 24.

49 Two excellent studies of this subject have appeared recently: Burt and Kennedy, Congressional Review of Price Control, 101 U. OF PA. L. REv. 333 (1952), and Durham, Congressional Response to Administrative Regulation: The 1951 and 1952 Price Control Amendments, 62 YAIE I.J. I (1952). 
advance a detailed plan of action for future contingencies. Congress is understandably reluctant to grant broad powers without clearly limiting and defining their use. The administrative agency, however, cannot operate effectively unless it has considerable freedom of action. This dilemma is inherent in the nature of a program of economic controls, and is not simply a matter of personalities or "political climate." Hence a change in administration does not solve it.

The distribution of functions under the OPS program was far from satisfactory. With one hand Congress gave OPS broad discretion regarding basic strategy: it was possible to use comprehensive controls, to use selective controls of great or small scope, or even to do nothing at all. With its other hand Congress imposed a large number of minute restrictions on the administrative discretion. For example, it prohibited the use of the statutory authority in the case of toilets in railroad stations..$^{50}$

In addition, Congress attempted to keep OPS on a short leash by giving only very short grants of authority. Controls were imposed in January of 1951 under statutory authority expiring in June of that year. For all of July, while extension was still being considered, OPS was in a virtual straitjacket. When the law was finally extended ${ }^{61}$ substantial changes had been made which required major alterations in the OPS regulatory framework. ${ }^{63}$ During the fall of 1951, Congress spent additional time reconsidering these amendinents, but adjourned without altering them. By then it was November and only seven months remained until the next expiration date. During May and June of 1952 Congress again debated the future of controls. After the House had first voted to do away with them, a compromise was arranged giving OPS another ten months of life. ${ }^{63}$ The resulting uncertainty and confusion made it virtually impossible for OPS to do any real planning or to carry out a smoothly functioning program. ${ }^{54}$ For over half the time that controls have been in effect, the prospects for the future have looked so dubious that OPS was greatly hampered in dealing with major price control issues.

A healthier and more constructive atmosphere will exist only when there is a distribution of functions which recoguizes both the overriding responsibility of the legislator and the expertise of the administrator. Congress

50 Section 402(e) (v)(1) of the Defense Production Act of 1950, as amended.

511951 amendments: 65 STAT. 131 (1951), 50 U.S.C. APP. $§ 2061$ (Supp. 1952).

52 These included the Capehart Amendment, discussed supra, the Herlong Amendment, guaranteeing distributors inargins; the Fugate Amendment, wbich banned projected beef rollbacks; and the Butler-Hope Amendment, prohibiting the use of slaughtering quotas. The cbanges in OPS' regulatory framework required by the Capehart Amendment are discussed in detail in Heimann, supra note 17. For an analysis of all the amendments see Durham, supra note 49. The best account of the legislative development of the amendments is given by Burt and Kennedy, supra note 49.

531952 Amendments: Pub. L. No. 429, 82d Cong., 2d Sess. (June 30, 1952).

54 For example, Charles E. Wilson, the Director of Defense Mobilization, notes in his report for the third quarter of 1951: "Unlike the second quarter-wbich was one of marked progress in price control-the third quarter was essentially a period of delay and uncertainty because of legislative developments." Director of Defense Mobizization, ThIRd QuARterix Report to the President 34 (October 1, 1951). 
should not only create the statutory framework for the exercise of controls, but should retain some authority over strategic policy decisions. As for the tactical moves by which the basic strategy is implemented, these should be the primary responsibility of the administrative agency.

The four-level control structure which we have sketched is adapted to this division of functions. The four levels of operation-(1) stand-by; (2) selective controls over defense materials; (3) selective controls over the civilian economy; and (4) general controls-represent fundamental differences in strategy. During the cold-war period, the first level would, of necessity, be in continuous operation. As long as defense demands take up a substantial share of national production, some use should probably be made of the powers provided by the second level of operation. However, a change to the third or the fourth level should require Congressional authorization. The Executive Branch should be given himited power to invoke the third or the fourth level in case of a sudden emergency requiring immediate action. Such executive action should have a definite expiration date not exceeding 90 or 120 days. A smooth working relationship between Congress and the administrative agency would require the closest contact with the Joint Committee on Defense Production. Since it is frequently difficult to distinguish between "strategy" and "tactics," regular consultation with the committee on questions arising in the day-by-day operations of the program should be encouraged. .55

The threat of inflation will be with us for the duration of the cold war. Its exact form undoubtedly will vary greatly at different times. However, we can ignore it no more than we can ignore the threat to our military security. The emphasis of economic policy, just as of military policy, must be on preparedness. While we must strive to cope with present problems, we must above everything else be fully prepared to meet the far graver problems which the future may bring. It is no comcidence that economic policy parallels military policy. The two will be intimately enmeshed as long as our security is imperiled.

55 The improvement of Congressional review is discussed in detail by Burt and Kennedy, supro note 49 , at $368-7 \%$. 